\title{
The economic vote at the party level: Electoral behaviour during the Great Recession
}

\author{
Marco Giuliani and Sergio Alberto Massari
}

\section{Introduction}

The economic crisis deeply affected the political setting of the countries of the European Union. The deterioration of the economy, and the inability of governments to remedy the Great Recession effectively, triggered a clear reaction by the electorate. Many citizens were disappointed by the way the crisis was being handled. Almost everywhere, we saw a loss of approval for governing parties, considered responsible for the failure of the adjustment policies, and a parallel rise of parties previously placed on the political side-lines. There is no lack of examples: from the collapse of Pasok, which let the door open for the advance of Syriza in Greece, to the success of the extreme right of National Alliance in Latvia, and up to the rise of Jobbik in Hungary, or of Podemos and Ciudadanos in Spain.

Though multiple factors combine to determine the result of an election, the economic crisis played a central role in directing the voting choices of the electorate in Europe. The theory of retrospective voting, which examines the relationship between the economy and voting behaviour, is a useful tool for interpreting the effects of the crisis on the electoral dynamics (Lewis-Beck et al. 2012; Lewis-Beck and Whitten 2013). Put simply, the theory claims that support for governing parties is systematically affected by trends in the economy. The approval that incumbents enjoy is expected to increase when there is an improvement in economic conditions, whereas a phase of recession would lead the voters to punish governing parties at the ballot box. The validity of this theory has been proven at different times and in different contexts (Dassonneville and Lewis-Beck, 2014; Duch and Stevenson, 2008; Lewis-Beck and Stegmaier, 2013; AA 2018), although scholars still debate on a series of issues.

There are, for example, elements that bear on the mechanism for attributing responsibility for the running of the economy, and so contribute to bring about the greater or lesser importance the economic vote acquires in practice. It is believed that the electorate tends to act more consistently with the principles of economic voting when the responsibilities of the government in the economic field can be clearly identified. The importance of the clarity of responsibility has been recognised in a series of studies (Anderson, 2000; Nadeau at al., 2002; Powell and Whitten, 1993), where the accent has been mainly placed on elements that are internal to the political system, such as the setup of the government (single party or coalition), and the institutional context it works within (presidential or parliamentary systems). 
However, elements that are external to the political system, such as the degree of openness of markets and the role of supranational bodies like the European Union, also appear to modify the mechanism for assigning responsibilities (Costa-Lobo and Lewis-Beck, 2012; Hellwig, 2001). Moreover, it has been suggested that the relationship between the economy and voting is asymmetric. Whereas punishment of incumbents is certain in times of crisis, the reward is uncertain when the economy is in good health (Singer, 2011; 2013).

Although the actual functioning of the mechanism underlying the theory still has some areas of uncertainty, it is the most important point of reference for studying the relationship that applies between the economy and voting. The principles of retrospective voting are thus the starting point for our analysis. Our aim is to assess the impact of the Great Recession on the electoral dynamics in Europe, and to do this we use a dataset including the results of 89 national elections that were held in the EU countries from April 2003 to December 2015. We initially deal with testing the theory of economic voting, i.e. assessing the impact of the crisis on approval for incumbent parties. However, more than focusing on the aggregate outcome of the poor state of the economy during the crisis, we will move our analysis to the party level, by relaxing what has been called the 'Constant Economic Vote Restriction' (Williams, Stegmaier and Debus, 2017).

By so doing, this work can tackle two important empirical puzzles identified by the recent literature on the topic. On the one side, for incumbents, the way in which the blame is distributed amongst coalition partners, having the clarity of responsibility of single-party government as benchmark model. On the other, for non-incumbents, what are the assets that permit to take advantage from the punishment of government parties, especially in a period in which new political actors entered the competition at the national level, and had to position themselves along the relevant political divides. We thus checked more than 800 electoral performances, distinguishing those who ruled in the previous legislature and those not, and, within the first group, the support for the party of the chief of the executive from that of its allies. We further assessed the role played by the party's ideological position, its radicalism, and its attitude towards the European Union on its electoral performance during the Great recession. We additionally looked at the results of parties that competed in the ballot for the first time, with the view that being free from responsibilities of any kind facilitated their success even more than what happened to opposition parties.

The article is organised in the following way. Next section critically reviews some of the assumptions of the theory of retrospective voting applied to a crisis period, and presents our hypotheses in the context of the previous empirical evidence. Section three describes the data we are using and presents the model. Section four sets out the results obtained and discusses their implications. The final section summarises and concludes. 


\section{Voting in tough times}

This work sets out from the robust results of the theory of economic voting, even once the retrospective mechanism is applied in a period of global crisis. When the economy is doing well, incumbents benefit electorally or, at worst, rely on their approval holding. When the economy is going badly, they are the ones who pick up the bill. And things go as badly for them the more the situation becomes serious.

It should not be taken for granted that what applies in normal times, applies a fortiori even during a widespread, deep, and persistent crisis like the one that affected globally the world economies since 2008. First of all, in this period all European countries experienced the crunch. Methodologically speaking, there could be a risk of no variation (Lewis-Beck and Costa Lobo, 2017). It is not that the severity of the crisis was identical, but it is reasonable to expect a restricted variance in the mass perception of the economy (Fraile and Lewis-Beck, 2014), and some common threshold effect. In case of negative growth, for instance, all government could experience a similar defeat, without making much difference between a 1 point or a 3 point-recession. In that event, whereas the theory expects defeats that are proportional to the state of the economy, the common disappointment for a no-growth period would produce identical (i.e. non proportional) electoral results.

Secondly, that possibility is even more commanding if we keep in mind that voters may yet apply retrospective evaluations, but having different benchmarks (Hansen, Olsen and Bech, 2015; Kayser and Peress, 2012; Stegmaier, Lewis-Beck and Park 2017). Citizens may consider the actual macro-economic performance of their own country, or its change compared to the more or less recent past, or even the relative accomplishments compared to other countries, or to the average European or World situation. In normal times, with moderate fluctuations of the economy, these alternatives may probably produce fairly consistent results. However, during the Great Recession, countries experienced severe shocks, with tens points of difference in growth among them, and even for the same economy in different periods at a short distance.

Finally, a crisis is by definition something qualitatively different ${ }^{1}$. The term is 'usually reserved for the most protracted periods of uncertainty, instability, and panic' (O'Hara, 2008: 484). In these periods, the circumstances may alter the retrospective voting behaviour of normal times. After protracted period of stagnation, citizens may overreact or become immune to changes in the economy. Voters may channel their concerns out of the ballot, abstaining or voicing their dissatisfaction in non-traditional ways. Reduced levels of turnout, with an electorate composed mainly by citizens loyal to the mechanism of

\footnotetext{
${ }^{1}$ Lewis-Beck and Costa Lobo (2017) clearly disagree on this statement, at least as far as the economic vote is concerned: “The crisis result, then, of greater economic impact, is not really paradoxical. It merely reflects the usual workings of valence economic voting as it operates to build the electoral outcome. In that sense, even ordinary economic voting becomes extraordinary if enough people engage in it, as they do in crisis time" (625).
} 
electoral representation, is in itself a challenge to the empirical confirmation of the theory of retrospective voting (Weschle, 2014).

Many scholars, starting from Powell and Whitten (1993), under the label 'incumbent' include all the governing parties taken collectively (Bartels, 2014; Dassonneville and Lewis-Beck, 2014). Many others, like Le Duc and Pammet (2013) or Larsen (2016), just focus on the party of the chief of the executive, avoiding to consider all the partners in coalition. Bengtsson (2004) and Kriesi (2014) propose a mixed strategy, checking separately the impact on the prime minister party, and that of all the incumbents together, even in order to demonstrate some differentiating effect of the economy on their fate. At this regard, two suppositions usually guide the empirical analysis.

On the one side, the assumption that the prominent role of leading the executive corresponds to the attribution of greater responsibilities (Duch and Stevenson, 2008; Fisher and Hobolt, 2010), and thus to larger electoral changes. Hernández and Kriesi (2016), for example, found that prime ministers' parties are systematically damaged by the crisis, on top of being harmed for being in government1.

On the other, the second belief maintains that the difficulties in assigning the responsibilities in case of coalition government (Anderson, 2000; Powell and Whitten, 1993; Silva and Whitten 2017), or simply their dilution among a greater number of actors (Lewis-Beck, 1996), permits to avoid part of the blame for a negative economy, and limit the collective damage in the ballot. Bengtsson (2004), for example, found that economic variables better explain electoral performance when there is a clear pattern of responsibility (a mix of stability, single-party and majority government). Hobolt, Tilley and Banducci (2013) use an additive index and conditional models to demonstrate that government clarity affects positively the impact of economic evaluation on incumbent vote intentions. And recently, Williams and Whitten (2015), obtained similar results through a sophisticated model combining the theoretical hints of the literature on spatial analysis with the suggestions of the one on retrospective voting ${ }^{2}$.

The two propositions are often quoted together (Stegmaier, Lewis-Beck and Park 2017), yet they move from difference stances, and are only rarely tested in the same equations. While the greater responsibility and punishment of the party of the chief executive rests on its visibility and prominence, the blurring effects relies exactly on its contrary, on the opacity in the attribution of responsibilities. Models testing the impact of leading the executive are not always interested in the blurring effects of coalition governments, and don't control for that variable. In turn, models focusing on clarity of responsibility often disregard the distinction between being the prime minister party or a partner in a coalition. But keeping the two aspects together is essential in understanding how the blame is distributed.

Prime minister parties are supposed to be the ones that pay the most in tough times, but if the blurring coalition effect is correct, they even should be able to exploit their leadership position in order to reduce the electoral costs of the crisis. As a matter of fact, more than their partners, they can exercise their heresthetic capacities (Shepsle, 2003) and profit from their diffused presence in the media in order 
to manipulate the common understanding of the economic situation, claim some positive results, and avoid at least some of the blame.

The German case is often used for testing these sort of propositions, since it has both a simple format of coalition government, and a clear leadership in the Chancellor. Debus, Stegmeier and Tosun (2014), analysing survey data from 1987 and 2009, demonstrate that the leading party of the coalition manages to disproportionally benefit from positive evaluations of the economy. Williams, Stegmaier and Debus (2017) confirm the supporting effect for the party of the Chancellor in case of positive evaluations - yet admitting not being able to demonstrate if it is produced by the role, or by being the largest party in coalition - while they concentrate on how the CDU and SPD gain from being in opposition the more negatively the public evaluates the economy. Even Angelova, König and Proksch (2016), by examining the patterns in the attribution of responsibility for a large set of policies in the case of the CDU/CSU and FDP German government during the period 2009-2013, found similar results, yet with 'the larger coalition party [being...] held more strongly responsible for dissatisfactory evaluations (and rewarded for satisfactory evaluations) than its junior partner' (p. 143).

Thus, the lesson that we learn from the German case can be certainly applied to good times, but, as far as the leadership effect is concerned, more ambiguously to bad times. Even Fisher and Hobolt (2010), who explicitly check both the blurring effect of coalitions, and the concentration of the blame of leadership, using 37 survey from the Comparative Study of Electoral Systems project, make a much clearer case for positive rather than for negative retrospective evaluations. Actually, for those who think that the executive did a very bad job in running the economy, the (very low) probability of voting for the party of the chief executive is practically the same as the one for the partners in coalition. Already for those who simply think the government did a bad job, there is a relative advantage of the leading party, something that gradually increases in case of positive and extremely positive evaluations.

In fact, during exceptional times such as the Great recession, the game of blame avoidance may be even more crucial than in normal times, producing clearly asymmetric results. In those extraordinary periods, prime ministers are key actors exploiting their leadership position, and profiting the most from the blurred responsibilities, in order to reduce the electoral costs of the crisis. As a matter of fact, more than their partners, they can exercise their heresthetic capacities (Shepsle, 2003), and take advantage from their diffused presence in the media in order to manipulate the common understanding of the economic situation, claim some positive results, and avoid (part of) the blame. This positional advantage compared to minor partners can be substantiated by three observations related to the actual dynamics of the crisis, especially in Europe. Firstly, the confounding constraints put by international actors such as the European Union and the International Monetary Fund (Armingeon and Guthmann, 2014), gave to prime ministers the chance of appearing to have fought a harsh battle in defence of the national economy, thus producing a diversion of responsibilities outside the national borders (Costa-Lobo and Lewis-Beck 2012; 
Hobolt and Tilley, 2014). Secondly, the perceived necessity not to disperse the consent in periods that require swift action, may drive citizens to relatively disregard minor parties, and prefer decisiveness against representation. Thirdly, compromising on austerity policies, without actually leading them, is something negatively perceived by supporters of the junior partners in coalition (Fortunato, 2017; Fortunato and Adams, 2015).

For these reasons, if correctly verified by comparing prime ministers' and partners' parties only within coalition governments, and by controlling for the direct effect of the previous support level (Stegmaier, Lewis-Beck and Park 2017) ${ }^{3}$, we argue that costs and opportunities of the prominent position enjoyed by the chief of the executive may cancel out in time of crisis, thus justifying:

Hp1. The party of the prime minister should not suffer from the crisis more than its potential incumbent partners, but it should comparatively benefit more from a positive state of the economy;

Moving from the dynamics of losing to the ones, less investigated, of winning during the crisis, those who benefit almost by definition are the new parties ${ }^{4}$. Parties that compete for the first time in a general election can only be winners. However, what most literature avoids to do is to check whether the magnitude of that victory is proportional to the negative state of the economy. The reward-punishment model relies on a typical exit-voice mechanism. The dissatisfaction produced by the deterioration of the economy first targets incumbent parties, favouring the opposition ones. Next, it addresses all legislators, favouring new actors, the only ones that can reject any blame for direct or indirect responsibilities for the present state of affairs. In normal times, new parties come and go almost randomly. But we suggest that, during the Great recession, the benefits of the incumbent losses mostly felt beyond the opposition. For this reason:

Hp2. The deeper the crisis, the greater the success of new parties.

According to a number of scholars, the political colour of parties may represent an advantage/disadvantage in times of crisis. Lindvall (2014) summarizes the reasons that support the so called 'swift-to-the-left' and 'swift-to-the-right' hypotheses. Left wing parties defend the more exposed from the costs of the crisis, and support policies that can soften its effects. Right wing parties play on the protection of national interests either from financial capitalism or from those who, such as immigrants, are seen as being able to buy out the few resources there are.

The evidence produced at this regard is not decisive. According to Le Duc and Pammet (2013), center-left government suffered the most from the crisis, and Stevenson (2001) offers the explanation that recession produces a right-shift of the aggregate policy preferences of the electorate (but contra 
Ferguson, Kellstedt and Linn 2013). In their seminal work, Powell and Whitten (1993) only partially found confirmation to the hypotheses that right-wing and left-wing parties are sensitive to different economic indicators. Applying their coefficient to the situation of low inflation and high unemployment produced by the Great recession would mostly go to the detriment of the latter. Lindvall (2014), comparing the Great Depression of 1920 with the Great Recession of 2008, maintains that only in the short run rightist parties benefit from the crisis, whereas its persistence systematically favours leftist ones. However, Bartels (2014), through a series of conditional models, finds no confirmation of whatever hypotheses concerning the role of ideology on the electoral success. Thus, we prefer to adjudicate the issue empirically by starting from the null hypothesis:

\section{Hp3. The depth of the crisis is not systematically associated with any advantage granted by specific ideological positions.}

Even if left and right are not directly relevant, this does not mean that this fundamental political dimension is not important under a different perspective. What if both preceding hypotheses were right, simply cancelling out any direct statistical effect? In that event, moderate parties would suffer due to poor trends in the economy, while radical parties may be found to be among those drawing a greater advantage from the crisis.

In the last decade there has been a real proliferation of qualitative and quantitative studies describing and explaining the rise of radicalism from both sides of the political spectrum. The dissatisfaction fuelled by the poor state of the economy is one of the variables thought to be at its origin. The birth and success of radical left parties (March and Rommerskirchen, 2015; Rooduijn and Akkerman, 2017; Visser et al., 2014) and radical right ones (Arzheimer and Carter, 2006; Mudde, 2014; Norris, 2005) may partially share the same causes, and even some socio-economic characteristics of their electorate. If this is true, at least in what concerns the impact of the crisis, there could be no left or right electoral bias in the Great Recession, but simply an erosion of the moderate support in favour of the extremes of the continuum. This is what even Hernández and Kriesi (2016) found, using their own classification of parties among five groups, including 'radical left' parties and 'populist radical right' ones. ${ }^{5}$

For these reasons, we maintain that:

Hp4. The deeper the crisis, the greater the success of radical parties.

It is important to underline that all our hypotheses have an 'other things being equal' caution. That means that radicalism should have its own explanatory power, after controlling for the fact that extreme parties are often new or in opposition, or for other characteristics such as their degree of Euroscepticism. ${ }^{6}$ The latter can be considered in Europe as a plausible alternative explanation for the 
success of parties during the crisis (Costa Lobo and Lewis-Beck, 2012; Van Elsas and Van der Brug, 2015; Werts, Scheepers and Lubbers, 2012).

Some observers have claimed that the crisis has been amplified more than tackled by the policies proposed by supranational authorities such as the International Monetary Fund and the European Union. Especially the Stability Pact, and the requirements for granting loans aimed at overcoming the risks of default connected with the sovereign debt crisis, are said to have prevented the growth needed and have caused several countries to go into a spiral characterised by economic recession, high debt and high unemployment. A situation that is explosive not only from the economic standpoint, but also because of the assessments concerning a surrender of national sovereignty to the Troika and the growing dissatisfaction with the way democracy works (Armingeon and Guthmann, 2014; Ruiz-Rufino and Alonso, 2017). This dissatisfaction can easily lead to the choice of punishing parties that appear more closely aligned with, if not actually participant in these supranational policies, to the advantage of parties that are seen as being free from these responsibilities if not openly hostile to models of governance that are supranationally shared.

This leads to our last hypothesis:

Hp5. The deeper the crisis, the greater the success of Eurosceptic parties.

\section{Data, operationalization, and method}

To test our hypotheses, we use an original dataset made by 820 observations, though the actual number of cases varies from model to model depending on the listwise deletion of missing information. The unit of analysis is the single party at the time of each of the 89 national ballots that occurred in the 28 countries of the European Union in the period between their last election before the crisis started in 2008 until the end of 20157. Thus, depending on the timing of elections and their internal instability, there are a minimum of two and a maximum of six elections per country included in the dataset. We consider all the parties that got at least $1 \%$ of the votes at the ballot box, or obtained a seat in parliament. This corresponds to a minimum of two parties in the 2003 election for the Maltese parliament, to a maximum of 17 in the 2015 election in Croatia.

In Table 1 we report the main elements describing our data: the elections included for each country and the minimum and maximum number of parties competing in these occasions.

*** TABLE 1 here *** 
Our dependent variable is the difference in support, computed in vote percentage points, between two consecutive elections. ${ }^{8}$ The party that lost most in absolute terms, more than $30 \%$, is Pasok, which was in government at the time of the elections in Greece in May 2012. Other cases of heavy defeats were Positive Slovenia, the Irish Fianna Fail and the Hungarian Socialist Party, all incumbents who suffered losses of around 25\%. At the opposite extreme we find a party such as the Citizens for European Development of Bulgaria, which gained almost $40 \%$ of votes at its first appearance at the election in 2013. Further examples of success at the first electoral outing are the Party of Myro Cesar in Slovenia in 2014, and the Five Star Movement in Italy in 2013.

Sizes of losses and gains are not boundless. A part from being logically restricted between $-100 \%$ and $+100 \%$, they are substantively restrained by the lagged support of the party, that is by the percentage of votes received in the preceding election. A big party with, let's say, $40 \%$ of the votes, can lose a lot, whereas a small one cannot. At the same time, for that first party it is extremely improbable to gain a further $10 \%$ of votes, whereas it is not that implausible for a small one or even for a new party. In other terms, changes in support have to be controlled in the right-hand part of the equation for their lagged value. In doing so, the relevant coefficients already discount for simple and direct effects of previous support, whose impact is made constant.

Our independent variable measuring the depth of the crisis is recession, i.e. the opposite of the growth index, computed on the twelve months preceding the election. There are three reasons justifying this choice. Firstly, its conceptual breadth and its association with the public perception of the relevance of economic issues makes it an ideal measure adopted by many scholars (Lewis-Beck and Stegmaier, 2013; Singer, 2011; van der Brug, van der Eijk and Franklin, 2007). Secondly, it affects all the other quantities. Apart from the fact that other macroeconomic indicators, included unemployment and deficit, can be more directly manipulated in the short run by policy-makers, recession has a direct bearing on both of them. Thirdly, recession (as the opposite of growth) avoids most of the methodological critiques addressed to other indices used in the literature on economic voting, such as those of being ideologically biased (Hibbs, 1987), or exposed to micrological fallacy (Dassonneville and Lewis-Beck, 2014). Using the previous 12 months (i.e. four trimesters) as temporal horizons of the voter is consistent with most of the literature, and is preferable and more accurate than simply considering the annual value of the previous year, which cannot account for the differences between a ballot that takes place in January or December.

To control for the possibility of dynamic effects, i.e. for a relative evaluation of the country's recent economic performance (Hernandez and Kriesi, 2016), we introduce in all our equations an index measuring the change in growth compared to the preceding year. The importance of this control is evident if we just give a look to the three hardest situation of crisis in our dataset, each of them produced by different trend dynamics. The worst situation at the time of an election was that of Greece, at the eve of its two elections of 2012 . It had a recession of $8.7 \%$, further depressing of another $0.6 \%$ the already 
dramatic level of the preceding year. The second severest crisis was that of Latvia, before its autumn 2010 election, with almost $8 \%$ recession, but this time consistently improving upon the previous year, in which recession was roughly $13 \%$ (i.e. with a positive change in growth of almost $5 \%$ ). The third example is Hungary in the spring of 2010 , with just about $5 \%$ recession, yet mostly produced in the 12 months preceding the election, since the year before the index was lower than $1.5 \%$. And the same could be said for the booming but extremely volatile economies of Eastern Europe before the crisis. In fact, the two indices, recession and change in growth, show high cross-country and longitudinal variability, thus justifying the necessity to account for those different trajectories within our models.

We characterize parties mainly relying on pre-existing and consolidated measures. For their leftright position we use the scale ranging from zero to ten proposed by Döring and Manow (2015). Our measure of radicalism profits from these same data. We subtracted the position of each party on the leftright scale to the central value of the distribution, and squared this difference in order to obtain only positive values. Each step towards a more extreme position thus translates into more than proportional increases of our index.

Eurosceptic positions are shared in very different countries. By the Northern League in Italy and the National Front in France, countries of the Euro area and founders of the European community, as well as by Ukip in the United Kingdom and Jobbik in Hungary, that do not adopt the common currency. If it is true that the parties mentioned are all radical right wing parties (Werts et al., 2012), Euroscepticism is not a trait that is exclusive to that political area. The literature shows rather that there is a 'u-shaped relationship' with the fundamental left-right cleavage of European politics. Euroscepticism is stronger at the extremes of that spectrum, whereas moderate parties and their electorate generally support the European Union and its policies. In order to measure this dimension, we use Chapel Hill expert surveys (Bakker et al., 2015). More specifically, we reverse their ordering, and integrate it for some recent missing values, both using the whole scale, or recoding it in order to obtain a classification of pro-EU, neutral, and Eurosceptic parties.

The literature on retrospective voting often recommends checking for relevant contextual factors, but less frequently coherently introduces the necessary controls. Among the most important ones, political institutions provide a filter for voting behaviours by moderating or amplifying certain dynamics. In proportional electoral systems, which are more permissive, the rise of new parties is more likely, along with the volatility of the preferences of voters, who for this reason are not fearful of seeing their ballot cast go to waste. The opposite occurs in majority and plurality systems. Moreover, the presence of several parties impacts upon the electoral dynamics, either due to the increased competition, or to the greater choice voters have (Rowe, 2015). Thus, electoral and party systems have a bearing on the dynamics we intend to study. For this reason, we include Gallagher's index of disproportionality and the effective number of electoral parties of Laakso and Taagepera as control variables. 
But even the level of turnout and the presence of coalition governments can confound the investigated relationship. In case of low turnout, smaller fluctuations of voters translate into higher percentage changes, magnifying an otherwise low volatility (Bengtsson, 2004). Coalition governments, as we clarified, not only mitigate the investigated effect due to less clear responsibilities, but even risk to muddle simple relationships regarding government parties due to statistical artefacts (van der Brug, van der Eijk and Franklin, 2007). In fact, the more government parties there are, the less they individually lose whatever their characteristics. Thus, it is always better to introduce at least a dummy variable for controlling for that effect. Eventually, since there are cases in which the incumbent government was in charge by only a few months at the date of the election, and others in which it fully completed its mandate, we check for the influence of the different timings of their appointment.

\section{Empirical results}

Our research design requires a series of interactions between the state of the economy and the different party features. As it has been observed, in conditional models 'each variable involved in the interaction terms [...] has multiple effects, not any single, constant effect, such as might be given somehow by a single coefficient' (Kam and Franzese, 2007: 20). For this reason, 'the analyst is not directly interested in the significance or insignificance of the model parameters per se' (Brambor, Clark and Golder 2006: 8), but should rather 'plot $\partial \hat{y} / \partial x$ over an appropriate range of zalong with confidence intervals' (Kam and Franzese, 2007: 46) and superimpose the 'frequency distribution for the variable on the horizontal axis' (Berry, Golder and Milton, 2012: 16). Following these methodological advices, we thus propose our results by plotting the marginal conditional effects, and reporting the complete coefficients only in the supplementary material.

The left panel of figure 1 represents the baseline of the economic vote theory, simply confirming the negative impact of recession for incumbents. The plotted line represents the marginal effects of being in government on the party's electoral prospects at different levels of recession, together with their 95\% confidence intervals. Wherever the latter don't overlap the horizontal zero line, we can safely reject the null hypothesis regarding the impact of incumbency on electoral performance. The superimposed histogram represents the frequency distribution of the observations in our sample, in order to have an immediate perception of the substantive relevance of our relationship, and check the relative amount of cases in the different portions of the conditional variable. In our model, the graph shows that when the economy is going badly, the right-hand side of the plot, incumbent parties lose approval. The worse the economy goes, the more incumbency is a handicap. This impact at the party level has to be assessed on the background of its opposite, which includes and cumulates the effects of being new and in opposition 
(see infra). Since the crisis fostered a high extra-systemic volatility, the poor and non-systematic gains obtained by incumbents even during elections that took place in situations and countries experiencing some germane growth, are evaluated even against the proliferation of new parties. Having a null marginal effect in the left part of the graph thus means that incumbent parties, on average, are as successful as a mix between opposition and new political subjects, with the latter being successful by definition

*** FIGURE 1 here ***

We should evaluate each of our hypotheses always keeping in mind this baseline model as benchmark. We start with the one regarding leading the executive, that can be ascertain only in the subset of coalition governments, thus evaluating the relative effect of recession on the (in)success of the party of the prime minister compared to that of the junior partners. The right panel of figure 1 helps understanding how punishments and rewards are distributed among those two different types of incumbents.

In case of recession, or even extremely feeble growth, something that happened for approximately $30 \%$ of our observations, there aren't any systematic difference in electoral performance between leading the coalition and being just a minor partner. This can be seen by the fact that in the right-hand side of the graph, the confidence intervals overlap with the axis representing the null effect. In all the other circumstances, the party of the chief of the executive enjoys a clear advantage on its associates. This does not mean that it necessarily wins the election, since from our baseline model we know that incumbency is an asset only in case of sustained growth, but that a good state of the economy favours the prime minister more than its allies.

It is not difficult to think of some relevant cases exemplifying this mechanism. The British election of 2015, though played even on other issues, illustrates how the incumbent ticket should not necessarily be evenly split or impair the leading party. The case is particularly interesting, considered the tradition of single-party government which had the Cameron-Clegg executive as the only exception since World War II. Nonetheless, it has not been difficult for the Conservative party to exploit its agenda advantage and claim for itself the partial successes of the economy, while distancing from the less reassuring figures of the national deficit. Eventually, the British electorate concentrated the incumbents' costs on the minor party of the coalition. And the same happened in 2011 in Denmark, where Rassmussen executive was yet defeated, but his Liberal party marginally increased its support whereas the Conservative ally suffered a clear collapse. Germany in 2013 is another example. Angela Merkel obtained for the Christian-democrats the best electoral performance since the Kohl era, while the Liberaldemocrats lost almost $10 \%$ of the votes, even failing to meet the $5 \%$ threshold of representation. 
The party of the chief of the executive thus profits more than the others when the economy is growing, can avoid some of the costs of stagnation, and even in the worst situation it does not systematically pay for its predominant trait more than its allies. As we saw while introducing our hypothesis, the literature has often underestimated this comparative advantage, frequently assuming that the front-line position enjoyed by the prime minister should translate automatically and symmetrically in greater benefits and greater losses.

The reasons for these contrasting findings can be manifold. Firstly, it could be a qualitative difference between normal times and the exceptionality of the Great recession. The latter called for uncompromised and swift decision-making capacities that junior partners could not assure, while many of the empirical analyses supporting the idea that leading the executive can only magnify symmetric costs and gains investigated more common fluctuations in the state of the economy (Duch and Stevenson, 2008). Secondly, the unit of analysis is relevant: many of these latter studies adopt individual level survey data, that cannot neatly distinguish what in the prime minister party triggers the dissatisfaction (Anderson, 2000; Debus, Stegmaier and Tosun, 2014). Thirdly, for the studies that use aggregated data, the difference can depend from the actual model tested. Comparing all prime ministers parties, included those in singleparty governments, to coalition partners, or an incomplete specification of the control variables, can favour a misinterpretation between role, size and leadership effects. ${ }^{10}$ Since the party of the prime minister is usually even the largest one, not distinguishing the effects of size from those of the premiership may reasonably confound the interpretation. Some major defeats, like the one of the UMP in the French 2012 election, can be better explained by the clearly different sizes of the two partner parties. Even in that case, due to the mechanism of the two-round election, the Nouveau Centre lost almost half of its MPs, relatively more than the leading Gaullist party.

We have hereto verified the negative effects of the crisis for incumbents. But who wins what government parties lose in tough times? We believe that, during a long-lasting crisis, the punishment extends itself beyond the incumbents, partially including even opposition parties, that cannot entirely capitalize from the retrospective mechanism (Plescia and Kritzinger, 2017). The space left for extrasystem volatility is not accidental, but proportional to the state of the economy. In the left panel of figure 2 , we compare the marginal effects for new parties, in the upper part of the graph with the usual dashed lines for the confidence intervals, to the ones produced by being in opposition, in the lower part with the lighter connected lines. In the period under consideration, novelty is clearly a plus. Its marginal effects are persistently positive and well distinct from zero. Additionally, the more the crisis developed into stagnation and then recession, the more these new parties capitalized the dissatisfaction and attracted the support of the voters. They gain more than opposition parties, even considering that the model already discounts the (negative) effect of their size in the previous election. The latter start to win only when the economy rests, and they don't recover the initial delay at higher levels of recession. Both slopes are clearly 
positive, but the one for new parties is a little bit steeper. This means that the disappointment turned into disenchantment, and even opposition leaders and parties were unable to intercept the confidence of those wanting to punish the outgoing political actors.

\section{*** FIGURE 2 here ***}

All these dynamics happen regardless of the proper political qualities of the different actors. Turning to the latter, many qualitative and quantitative accounts of what happened during the Great recession report an increase of right-wing parties. Yet, the logic of economic voting should be indifferent to any ideological, partisan or policy attachment (Bartels, 2014). With our third hypothesis, we decided that the issue needed to be tackled empirically starting by a null assumption.

The right panel of figure 2 confirms the validity of the retrospective mechanism. At no level of recession does ideology determine the electoral success or defeat of a party. The positive slope of the line, representing the effects of a one-unit change on the left-right scale on party's electoral performance, may give some reasons for the claims advanced by several studies. If we looked only at the average prediction, we would say that rightist parties fare better under recession. However, the confidence intervals are far from reporting any systematic effect of ideology, constantly overlapping the zero reference line. In the supplementary material (figure A.1), we demonstrate that, not even in the long run there is a relative advantage for left-wing parties (against Lindvall, 2014). To say it with a quip, economy (i.e. economic voting) does not care about political colour. That does not mean that there is no political regularity in electoral behaviour. Left-wing parties enjoyed a systematic advantage in the elections held under right-wing incumbents, and vice versa for right-wing parties where it was the left that was governing. The democratic mechanism of alternation, which is typical even in normal times, has been amplified in range and multiplied in frequency during the Great recession. ${ }^{11}$

*** FIGURE 3 here ***

In this game of alternating preferences, it is perhaps legitimate to expect that extreme parties came out of the crisis reinforced. This expectation is also consistent with a series of qualitative observations on electoral outcomes of first and second order elections held in Europe in the last decade. However, the systematic analysis conducted on the basis of our data does not support these impressions.

A poor state of the economy is indeed an environment that can be exploited by the more radical parties, as can be seen in the positive slope of the straight lines describing the marginal effects in the left panel of figure 3. On the opposite side, a growing economy represents a setting that seems to discourage radicalism, and for this reason the marginal effects are negative for more than half of our distribution. 
Yet, several other factors may prevent extreme parties from drawing systematic advantages from economic downturns. Additionally, we have to keep in mind that many radical parties are at the same time new, and perhaps Eurosceptic. Our models already control for those characteristics. In other words, we attribute to each asset its own effect, unpacking what is qualitatively viewed as a bounded whole. As a result, the confidence intervals reported in the left panel of figure 3 are so wide to cover entirely the zero reference line, so that the null hypothesis cannot be excluded, and consequently hypothesis 4 needs to be rejected.

This does not occur with our fifth hypothesis, the one related to Euroscepticism. ${ }^{12}$ In this case, as can be seen in the right panel of the same figure 3, recession clearly facilitates the success of parties that oppose European integration and the policies of the European Union. The opposite is also true. A thriving economy undermines most of the arguments of Eurosceptic parties, although its electoral relevance is confined by the large intervals that overlap the horizontal axis. Using the imaginative expression proposed by Otjes and Katsanidou (2017: 314), European integration is the 'giant that has finally awaken', and this dimension affected differently the citizens' attitudes in countries deeply or weakly touched by the Great recession. Using survey data, they demonstrate that the deeper the crisis, the more voter positions on the economic dimension is aligned with their positions on the European dimension. If it is accurate to say that most of our cases fall into a central grey area where no electoral effect is registered, it cannot be denied that the political message of a united Europe comes out of the crisis with notably reduced status. What was once seen as a solution, begins to be considered as part of the problem, if not the main factor in prolonging the economic emergency.

\section{Conclusion}

The literature on economic voting has demonstrated robustly that the health of the economy determines to a large extent the chances of governing parties holding on to power. Retrospective voting, much more than the ideological or policy preferences of voters, is a powerful cognitive shortcut in assessing the political offer. If the economy goes badly, voters punish those who are in office, whereas if it is going well, they reward them.

In this article, we have moved the analysis of retrospective voting to the party level. We analyzed what represented an asset and what a drawback during the long crisis. In tough times, and counterintuitively, the same electoral fate binds together all incumbents. However, when the economy progresses, are mainly those who lead the executive who gain electorally. Contrary to much of the literature in the field, we illustrated and explained why the leading effect cannot be symmetrical under opposite economic circumstances. 
In addition to what happened to incumbents, we focused on the impact of the crisis on the performance of other parties. 'Novelty' plays a distinguished role, as a sort of positive fixed effect of the whole period, that multiplies itself already with the first hints of economic downturn. The constant decrease in partisanship in Europe may have contributed to this sort of 'over-reaction' in the retrospective economic mechanism (Kayser and Wlezien, 2011) which, it should be noted, has little to do with the usual political traits of these parties. Novelty does not absorb entirely the dissatisfaction produced by the state of the economy. Even opposition parties gain from the defeats of incumbents, but only to a lesser degree and under a smaller range of circumstances. These two factors almost saturate the explanatory capacity of our models. The ideological position of parties, once discounted for those two effects, has no autonomous leverage. Being left-wing or right-wing does not count, not even in the long period. However, the magnitude of their successes and defeats enhances alternation and turnover. More than in normal periods, economic downturns drive voters to cast votes for the left when there are right-wing governments, and votes for the right when the incumbents are of the left. Radical parties are unable to exploit this situation systematically, although we demonstrated that the crisis can represents a fertile terrain for their call. Euroscepticism is much more important. Not only have Eurosceptic parties gained ground during the crisis (beyond being often non-incumbents and sometimes even new), but their success has been directly proportional to the severity of the recession.

Unpacking the impact of the Great recession for both incumbents and non-incumbents, together with the wide set of controls introduced in our models, is at the methodological core of this article. Our choices permitted to refine and integrate some of the traditional expectations of the theory of economic voting, and at the same time to revise substantially some accounts of the effects of the crisis. Yet, it is worth remembering that the disaffection with traditional politics, which led large part of the electorate to defect to new parties, is a mechanism that cannot last forever. On the one hand, because (fortunately) crises come to an end. On the other, because virginity in politics is used up rapidly and cannot be exploited repeatedly in election rhetoric. Many new leaders have already been put to the test, and the mechanism of retrospective voting has often reduced their appeal. The ones who gain from an economy in crisis, risk losing because of it just as quickly. 
Table 1. Countries, elections and number of parties in the dataset

\begin{tabular}{|c|c|c|c|c|c|}
\hline Country & Elections & Parties & Country & Elections & Parties \\
\hline Austria & $2006,2008,2013$ & $7-8$ & Italy & $2006,2008,2013$ & $12-16$ \\
\hline Belgium & $2007,2010,2014$ & $12-13$ & Latvia & $\begin{array}{l}2006, \quad 2010, \quad 2011, \\
2014\end{array}$ & $6-11$ \\
\hline Bulgaria & 2005, 2009, 2013, 2014 & $8-13$ & Lithuania & $2004,2008,2012$ & $10-13$ \\
\hline Croatia & $2007,2011,2015$ & $11-17$ & Luxembourg & $2004,2009,2013$ & $7-9$ \\
\hline Cyprus & 2006, 2011 & $7-8$ & Malta & $2003,2008,2013$ & $2-3$ \\
\hline Czech republic & $2006,2010,2013$ & $6-11$ & Netherlands & 2006, 2010, 2012 & $10-11$ \\
\hline Denmark & $2007,2011,2015$ & $8-9$ & Poland & $2007,2011,2015$ & $8-9$ \\
\hline Estonia & 2007, 2011, 2015 & $6-8$ & Portugal & $\begin{array}{l}2005, \quad 2009, \quad 2011, \\
2015\end{array}$ & $5-8$ \\
\hline Finland & $2007,2011,2015$ & 9 & Romania & 2004, 2008, 2012 & $7-10$ \\
\hline France & 2007, 2012 & $12-13$ & Slovakia & $2006,2010,2012$ & $9-12$ \\
\hline Germany & $2005,2009,2013$ & $7-9$ & Slovenia & $\begin{array}{l}2004, \quad 2008, \quad 2011, \\
2014\end{array}$ & $9-11$ \\
\hline Greece & $\begin{array}{l}\text { 2007, 2009, } 2012 \text { (May- } \\
\text { June), } 2015 \text { (Jan.- } \\
\text { Sept.) }\end{array}$ & $6-13$ & Spain & $\begin{array}{l}2004, \quad 2008, \quad 2011, \\
2015\end{array}$ & $10-15$ \\
\hline Hungary & $2006,2010,2014$ & $6-9$ & Sweden & 2006, 2010, 2014 & $8-9$ \\
\hline \multirow[t]{2}{*}{ Ireland } & 2007,2011 & $6-8$ & United Kingdom & $2005,2010,2015$ & $11-13$ \\
\hline & & & Total & 89 & 820 \\
\hline
\end{tabular}

Sources: http://www.parlgov.org/; http://www.parties-and-elections.eu/; https://www.wikipedia.org/ Notes: we excluded ethnical parties for which the electoral system assigns reserved seats 

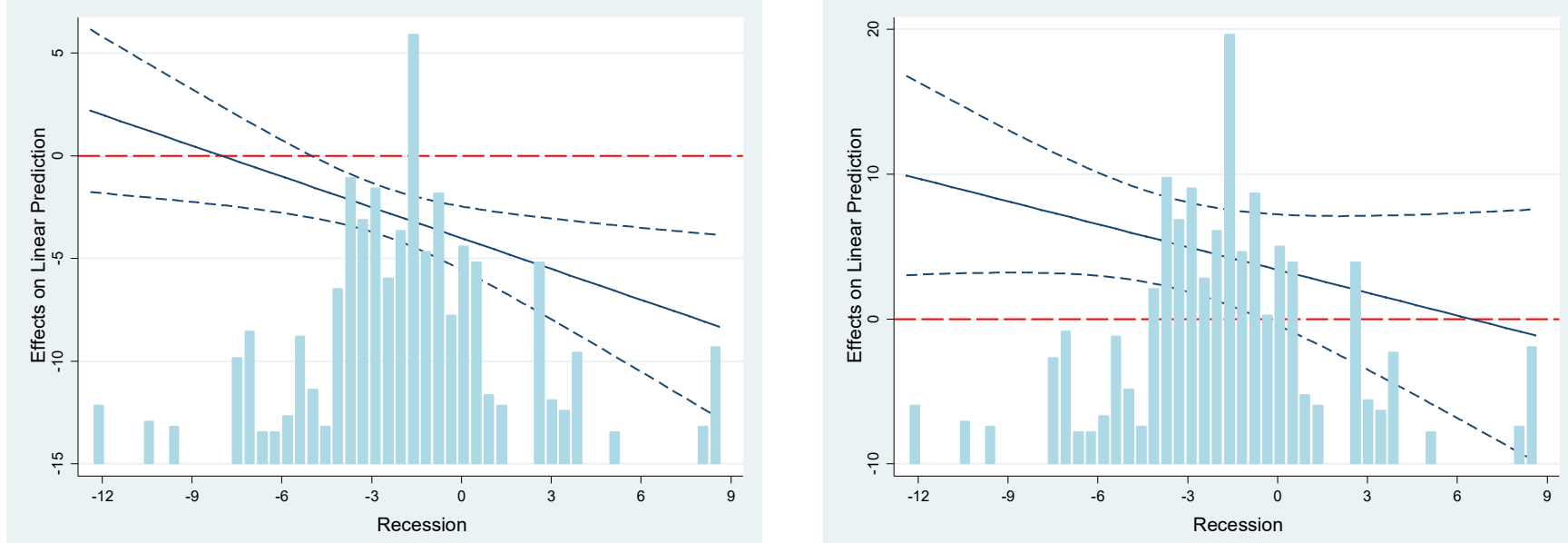

Figure 1. Marginal effects of being incumbent (left panel), and of leading a coalition executive (right panel) on electoral performance at different intensities of recession, with $95 \%$ confidence intervals.

Notes: Here, and in the other figures, histograms represent the distribution of our observations according to the different magnitudes of growth/recession. 

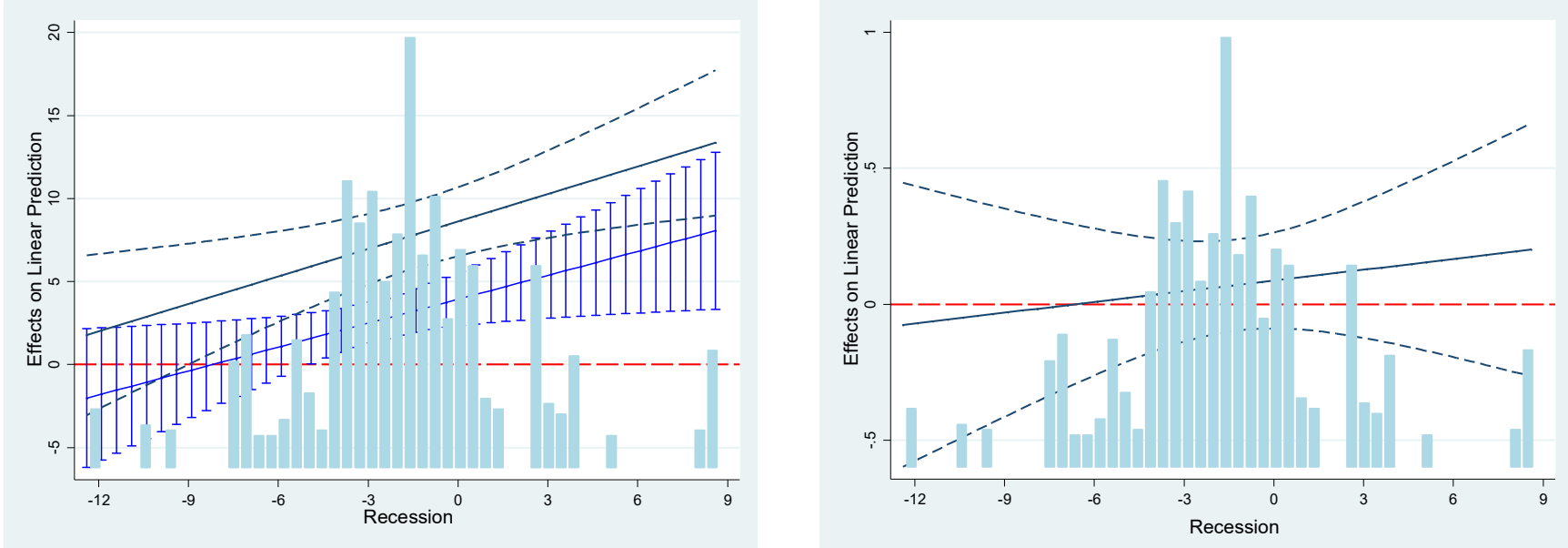

Figure 2. Marginal effects of being new (solid upper line with dashed 95\% confidence intervals) or in opposition (lower line with connected confidence intervals) in the left panel, and of ideology in the right panel, on electoral performance at different intensities of recession.
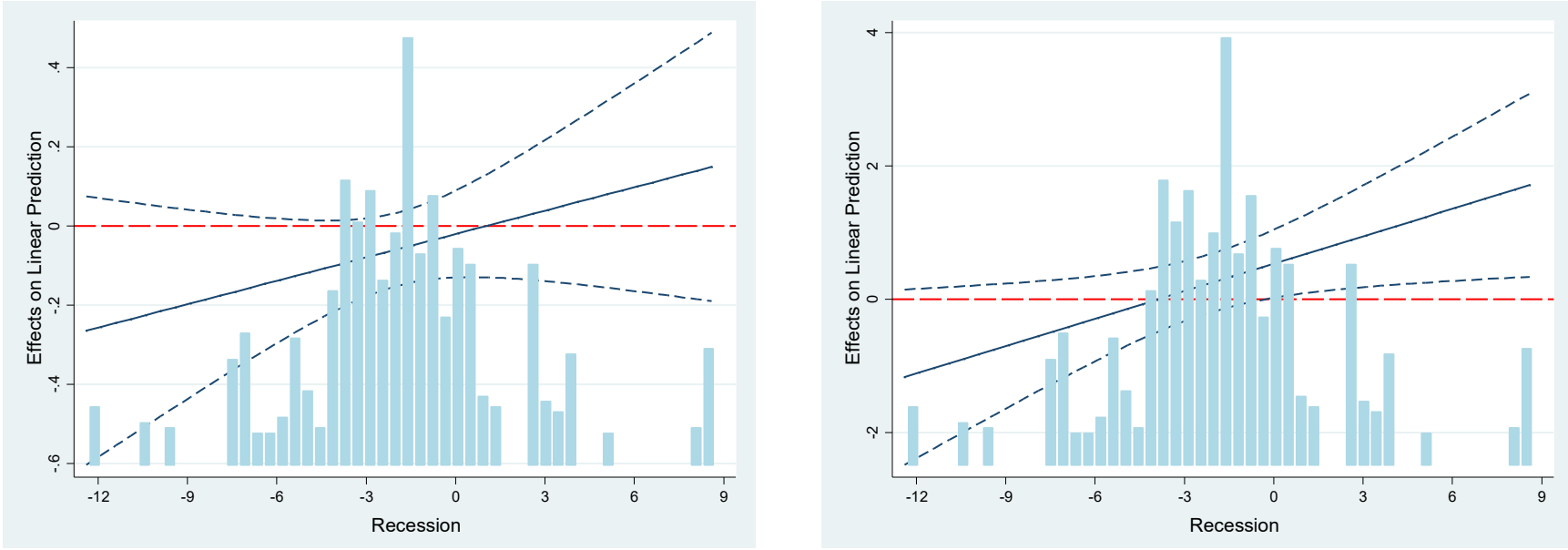

Figure 3. Marginal effects of radicalism (left panel) and Euroscepticism (right panel) at different intensities of recession, with $95 \%$ confidence intervals. 


\section{References}

Anderson C J (2000) Economic Voting and Political Context: A Comparative Perspective. Electoral Studies 19(2-3): 151-170.

Angelova M, König T and Proksch S O (2016) Responsibility attribution in coalition governments: Evidence from Germany. Electoral Studies 43: 133-149.

Armingeon K and Guthmann K (2014) Democracy in crisis? The declining support for national democracy in European countries. 2007-2011. European Journal of Political Research 53(3): 423-442.

Arzheimer K and Carter E (2006) Political opportunity structures and right-wing extremist party success. European Journal of Political Research 45(3): 419-443.

Bakker R, de Vries C, Edwards E, Hooghe L, Jolly S, Marks G, Polk J, Rovny J, Steenbergen M and Vachudova M (2015) Measuring Party Positions in Europe: The Chapel Hill Expert Survey Trend File 1999-2010. Party Politics 21(1): 143-152.

Bartels L M (2014) Ideology and Retrospection in Electoral Responses to the Great Recession. In Bermeo $\mathrm{N}$ and Bartels L M (eds) Mass Politics in Tough Times: Opinions, Votes, and Protest in the Great Recession. Oxford: Oxford University Press, pp. 185-223.

Bengtsson $\AA$ (2004) Economic voting: The effect of political context. volatility and turnout on voters assignment of responsibility. European Journal of Political Research 43(5): 749-767.

Berry W, Golder M and Milton D (2012) Improving Tests of Theories Positing Interaction. Journal of Politics 74(3): 653-671.

Brambor T, Clark W R and Golder M (2006) Understanding Interaction Models: Improving Empirical Analyses. Political Analysis 14(1): 63-82.

Costa Lobo M and Lewis-Beck M S (2012) The Integration Hypothesis: How the European Union Shapes Economic Voting. Electoral Studies 31(3): 522-528.

Dassonneville R and Lewis-Beck M S (2014) Macroeconomics. economic crisis and electoral outcomes: A national European pool. Acta Politica 49(4): 372-394.

Debus M, Stegmaier M and Tosun J (2014) Economic Voting under Coalition Governments: Evidence from Germany. Political Science Research and Methods 2(1): 49-67.

Döring H and Manow P (2015) Parliaments and Governments Database (ParlGov): Information on Parties. Elections and Cabinets in Modern Democracies. http:/ /www.parlgov.org/.

Duch R M and Stevenson R T (2008) The Economic Vote. How Political and Economic Institutions Condition Election Results. Cambridge: Cambridge University Press.

Duch R M and Stevenson R T (2013) Voter perceptions of agenda power and attribution of responsibility for economic performance. Electoral studies 32(3): 512-516.

Ferguson G, Kellstedt P M and Linn S (2013) How does the economy shape policy preferences? Electoral Studies 32(3): 544-550.

Fisher S D and Hobolt S B (2010) Coalition government and electoral accountability. Electoral Studies 29(3): 358-269.

Fortunato D (2017) The Electoral Implications of Coalition Policy Making. British Journal of Political Science doi:10.1017/S0007123416000430.

Fortunato D and Adams J (2015) How voters' perceptions of junior coalition partners depend on the prime minister's position. European Journal of Political Research 54(3): 601-621. 
Fraile M and Lewis-Beck M S (2014) Economic vote instability: Endogeneity or restricted variance? Spanish panel evidence from 2008 and 2011. European Journal of Political Research 53(1): 160-179.

Giuliani M and Massari S A (2018) AA (2018) It's the Economy, stupid. Votare in tempo di crisi, Bologna: il Mulino, forthcoming.

Hansen K M, Olsen A L, Bech M (2015) Cross-National Yardstick Comparisons: A Choice Experiment on a Forgotten Voter Heuristic. Political Behavior 37(4):767-789.

Hellwig T T (2001) Interdependence. Government Constraints and Economic Voting. Journal of Politics 63(4): 1141-1162.

Hernández E and Kriesi H (2016) The electoral consequences of the financial and economic crisis in Europe. European Journal of Political Research 55(2): 203-224.

Hibbs D A (1987) The Political Economy of Industrial Democracies, Cambridge: Harvard University Press.

Hobolt S, Tilley J and Banducci S (2013) Clarity of responsibility: How government cohesion conditions performance voting. European Journal of Political Research 52(2): 164-187.

Hobolt S and Tilley J (2014) Who's in Charge? How Voters Attribute Responsibility in the European Union. Comparative Political Studies 47(6): 795-819.

Kayser M A and Peress M (2012), Benchmarking across Borders: Electoral Accountability and the Necessity of Comparison. American Political Science Review 106(3): 661-684.

Kayser M A and Wlezien C (2011) 'Performance pressure: Patterns of partisanship and the economic vote'. European Journal of Political Research 50(3): 365-394.

Kam C D and Franzese R J (2007) Modeling and interpreting interactive bypotheses in regression analysis. Ann Arbor: The University of Michigan Press.

Kriesi H (2014) The Political Consequences of the Economic Crisis in Europe. Electoral Punishment and Popular Protest. In Bermeo N and Bartels L M (eds) Mass Politics in Tough Times: Opinions. Votes. and Protest in the Great Recession. Oxford: Oxford University Press, pp. 297-333.

Larsen M V (2016) Economic Conditions Affect Support for Prime Minister Parties in Scandinavia. Scandinavian Political Studies 39(3): 226-241.

Le Duc L and Pammett J H (2013) The fate of governing parties in times of economic crisis. Electoral studies 32(3): 494-499.

Lewis-Beck M S (1986) Comparative economic voting: Britain, France, Germany, Italy. American Journal of Political Science 30(2): 315-346.

Lewis-Beck M S and Stegmaier M (2013) The VP-function revisited: a survey of the literature on vote and popularity functions after over 40 years. Public Choice 157(3/4): 367-385.

Lewis-Beck M S, Costa Lobo M and Bellucci P (2012) Special Symposium: Economic Crisis and Elections: The European Periphery. Electoral Studies 31(3): 469-642.

Lewis-Beck M S and Whitten G D (2013) Special Symposium. Economics and Elections. Effects Deep and Wide. Electoral Studies 32(3): 391-562.

Lewis-Beck M S and Costa Lobo M (2017) The Economic Vote: Ordinary vs. Extraordinary Times. In Arzheimer K, Evans J and Lewis-Beck M S (eds) The SAGE Handbook of Electoral Behaviour. London: Sage Publications, vol. 2, pp. 606-629.

Lindvall J (2014) The Electoral Consequences of two Great Crises. European Journal of Political Research 53(4): 747-765.

Litton K (2012) Party Novelty and Economic Voting: The Evidence from the EU Parliamentary Elections. Paper prepared for the MPSA conference. Chicago (Il) April 12-15. 
Litton K (2015) Party novelty: Conceptualization and measurement of party change. Party Politics 21(5): $712-725$.

March L and Rommerskirchen C (2015) Out of left field? Explaining the variable electoral success of European radical left parties. Party politics 21(1): 40-53.

Mudde C (2014) Fighting the system? Populist radical right parties and party system change. Party politics 20(2): 217-226.

Nadeau R, Niemi R G and Yoshinaka A (2002) A Cross-National Analysis of Economic Voting: Taking Account of the Political Context Across Time and Nations. Electoral Studies 21(3): 403-423.

Norris P (2005) Radical Right. Voters and Parties in the Electoral Market. Cambridge: Cambridge University Press.

O'Hara P A (2008) Economic crisis. in William Darity (ed.) International Encyclopedia of the Social Sciences. New York: MacMillan, pp. 483-485.

Otjes S and Katsanidou A (2017) Beyond Kriesiland: EU integration as a super issue after the Eurocrisis. European Journal of Political Research 56(2): 301-319.

Plescia C and Kritzinger S (2017) Retrospective voting and party support at elections: credit and blame for government and opposition. Journal of Elections. Public Opinion and Parties 27(2): 156-171.

Powell G B and Whitten G D (1993) A Cross-National Analysis of Economic Voting: Taking Account of the Political Context. American Journal of Political Science 37(2): 391-414.

Rombi S (2016) European voters in the face of crisis: the prominence of unemployment. Italian Political Science Review 46(2): 151-173.

Rooduijn M and Akkerman T (2017) Flank attacks: populism and left-right radicalism in Western Europe. Party Politics 23(3): 193-204.

Rowe K T (2015) Making voice count: Economic voting and the number of parties. Party politics 21(5): 803-812.

Ruiz-Rufino R and Alonso S (2017) Democracy without choice: Citizens perceptions of government autonomy during the Eurozone crisis. European Journal of political Research 56(2): 320-345.

Shepsle K A (2003) Losers in Politics (And How They Sometimes Become Winners): William Rikers' Heresthetic. Perspectives on Politics 1(2): 307-315.

Silva T and Whitten G D (2017) Clarity of Responsibility and Vote Choice, In Arzheimer K, Evans J and Lewis-Beck M S (eds) The SAGE Handbook of Electoral Behaviour. Sage Publications: London, vol. 1, pp. 80-91.

Singer M M (2011) Who Says 'It's the Economy'? Cross-National and Cross-Individual Variation in the Salience of Economic Performance. Comparative Political Studies 44(3): 284-312.

Singer M M (2013) The global economic crisis and domestic political agendas. Electoral studies 32(3): 404410.

Stegmaier M, Lewis-Beck M S and Park B (2017) The VP-Function: A Review, In Arzheimer K, Evans J and Lewis-Beck M S (eds) The SAGE Handbook of Electoral Behaviour. Sage Publications: London, vol. 2, pp. 584-605.

Stevenson R T (2001) The Economy and Policy Mood: A Fundamental Dynamic of Democratic Politics? American Journal of Political Science 45(3) pp. 620-633.

van der Brug W, van der Eijk C and Franklin M (2007) The Economy and the Vote: Economic Conditions and Elections in Fifteen Countries. Cambridge: Cambridge University Press.

van Elsas E and van der Brug W (2015) The Changing Relationship Between Left-right Ideology and Euroscepticism.1973-2010. European Union Politics 16(2): 194-215. 
Visser M, Lubbers M, Kraaykamp G and Jaspers E (2014) Support for radical left ideologies in Europe. European Journal of Political Research 53(3): 541-558.

Weschle S (2014) Two types of economic voting: How economic conditions jointly affect vote choice and turnout. Electoral Studies 34: 39-53.

Werts H, Scheepers P and Lubbers M (2012) Euro-scepticism and Radical Right-wing Voting in Europe. 2002-2008: Social Cleavages. Socio-political Attitudes and Contextual Characteristics Determining Voting for the Radical Right. European Union Politics 14(2): 183-205.

Williams L K and Whitten G D (2015) Don't Stand So Close to Me: Spatial Contagion Effects and Party Competition. American Journal of Political Science 59(2): 309-325.

Williams LK, Stegmaier M and Debus M (2017) Relaxing the Constant Economic Vote Restriction: Economic evaluations and party support in Germany. Party Politics: 23(3): 286-296.

1 Yet, Dassonneville and Lewis-Beck (2014: 386) report that when they substituted as dependent variable the prime minister to the collective measure of incumbents vote share, 'the general effect of the economy appears halved'.

2 Again, Dassonneville and Lewis-Beck (2014: 383) are somehow out of the choir reporting 'no significant results' on their measure capturing the absence of clarity, i.e. the number of parties in government.

3 Incidentally, even Duch and Stevenson (2013) report laboratory evidence that individuals' heuristics tend to assign the responsibility for collective decisions to actors having agenda setting powers (the proposer), and to the largest parties. The two elements typically go together, and it is up to the researcher to disentangle that complex relationship by including the appropriate controls in her equations.

4 Our definition of 'new' refers to the fact that a party did not compete in the previous election. We do not enter into the debate of what constitutes the essence of their novelty. Litton (2015) demonstrates that only in a minor number of cases novelty implicates the change of name that we require, thus making our test intrinsically conservative. Her sophisticated approach considering different quality and degree of novelty in each party, and treating the latter as a conditional factor in the working of the retrospective mechanism (Litton, 2012) could not be replicated in this research.

5 The remaining three categories are 'new', 'mainstream' and 'non-mainstream' parties.

6 For example, Hernández and Kriesi (2016) code the Five Star Movement in Italy as a new formation for the 2013 election, whereas the Northern league counts as a radical right party. Rombi (2016), instead, considers both as Eurosceptic. They are all correct. However, in our models we control at the same time for each of those characteristics, not choosing which of them better describes the party: Thus, the Northern League is at the same time non-incumbent, non-new, rightist, radical and Eurosceptic, whereas the Five Star Movement is new, non-incumbent, comparatively leftist, and Eurosceptic.

7 While most agree in taking 2008 as the beginning of the Great recession, there is not a fixed date for the end of the crisis, and the official definition of recession as a two-quarter period of negative growth is not of great help once we deal with the longer terms political effects. Yet, we took 2015 of endpoint of our analysis because in that year most Eu countries (with the exception of Greece and Cyprus) completed the recovery of their pre-crisis GDP per capita levels.

8 In most cases, checking the correspondence between two units in subsequent elections is not problematic. In case of deep restructuring of the party system, it may sometimes prove difficult to 
assess the actual novelty of a party, follow processes of merger and fission, or uncover purely electoral marketing operations. In doubt, we preferred to overestimate the degree of novelty in presence of formally new organizations instead of underestimating the phenomenon.

9 See the supplementary material for the complete coding and descriptive statistics.

10 Descriptively, the average losses of prime ministers' parties in our sample is actually higher than those of their partners, but a) this is mainly due to the size effect that our model discounts and b) the range of performances for the first ones is wider.

11 See the figure A.2 in the supplementary material for a specific analysis of the issue.

12 We use here the entire scale derived by Chapel Hill surveys in order to profit from the more finegrained measure, in spite of the number of missing values. 